\title{
Article \\ Clinical, Histological, and Genetic Features of 25 Patients with Autosomal Dominant Progressive External Ophthalmoplegia (ad-PEO)/PEO-Plus Due to TWNK Mutations
}

\author{
Laura Bermejo-Guerrero $^{1}$ (D), Carlos Pablo de Fuenmayor-Fernández de la Hoz ${ }^{1}$, Pablo Serrano-Lorenzo ${ }^{2,3,4}{ }^{(D)}$, \\ Alberto Blázquez-Encinar ${ }^{2,3,4} \mathbb{D}$, Gerardo Gutiérrez-Gutiérrez ${ }^{5} \mathbb{D}$, Laura Martínez-Vicente ${ }^{6}$, \\ Lucía Galán-Dávila ${ }^{6}$, Jorge García-García ${ }^{7}$, Joaquín Arenas ${ }^{2,3,4}$, Nuria Muelas ${ }^{3,8,9}$, \\ Aurelio Hernández-Laín 2,10, Cristina Domínguez-González ${ }^{1,2,3, * \mathbb{D}}$ and Miguel A. Martín 2,3,4 (D)
}

1 Neuromuscular Unit, Department of Neurology, Hospital Universitario 12 de Octubre, 28041 Madrid, Spain; laura.bermejo@salud.madrid.org (L.B.-G.); carlosdefuenmayor@hotmail.com (C.P.d.F.-F.d.l.H.)

2 Hospital 12 de Octubre Research Institute (imas12), 28041 Madrid, Spain; pabloserra.lor@gmail.com (P.S.-L.); abencinar@hotmail.com (A.B.-E.); joaquin.arenas@salud.madrid.org (J.A.); aurelio.hlain@salud.madrid.org (A.H.-L.); mamcasanueva.imas12@h12o.es (M.A.M.)

3 Biomedical Network Research Centre on Rare Diseases (CIBERER), Instituto de Salud Carlos III, 28029 Madrid, Spain; muelas_nur@gva.es

4 Mitochondrial Disorders Laboratory, Clinical Biochemistry Department, Hospital Universitario 12 de Octubre, 28041 Madrid, Spain

check for

updates

Citation: Bermejo-Guerrero, L.; de Fuenmayor-Fernández de la Hoz, C.P.; Serrano-Lorenzo, P.; BlázquezEncinar, A.; Gutiérrez-Gutiérrez, G. Martínez-Vicente, L.; Galán-Dávila,

L.; García-García, J.; Arenas, J.;

Muelas, N.; et al. Clinical,

Histological, and Genetic Features of 25 Patients with Autosomal Dominant Progressive External Ophthalmoplegia (ad-PEO)/ PEO-Plus Due to TWNK Mutations. J. Clin. Med. 2022, 11, 22. https:// doi.org/10.3390/jcm11010022

Academic Editor: Daniele Orsucci

Received: 17 November 2021

Accepted: 20 December 2021

Published: 22 December 2021

Publisher's Note: MDPI stays neutral with regard to jurisdictional claims in published maps and institutional affiliations.

Copyright: (C) 2021 by the authors. Licensee MDPI, Basel, Switzerland. This article is an open access article distributed under the terms and conditions of the Creative Commons Attribution (CC BY) license (https:// creativecommons.org/licenses/by/ $4.0 /)$.
5 Department of Neurology, Hospital Universitario Infanta Sofía, 28703 Madrid, Spain; g3.neuro@gmail.com

6 Department of Neurology, Hospital Universitario Clínico San Carlos, 28040 Madrid, Spain; lmvicente@salud.madrid.org (L.M.-V.); lgaland@yahoo.com (L.G.-D.)

7 Department of Neurology, Complejo Hospitalario Universitario de Albacete, 02006 Albacete, Spain; jorgaga@sescam.jccm.es

8 Neuromuscular Unit, Department of Neurology, Hospital Universitari I Politècnic La Fe, 46026 Valencia, Spain 9 Neuromuscular and Ataxias Research Group, Instituto de Investigación Sanitaria La Fe, 46026 Valencia, Spain

10 Department of Neuropathology, Hospital Universitario 12 de Octubre, 28041 Madrid, Spain

* Correspondence: cdgonzalez@salud.madrid.org

\begin{abstract}
Autosomal dominant mutations in the TWNK gene, which encodes a mitochondrial DNA helicase, cause adult-onset progressive external ophthalmoplegia (PEO) and PEO-plus presentations. In this retrospective observational study, we describe clinical and complementary data from 25 PEO patients with mutations in TWNK recruited from the Hospital 12 de Octubre Mitochondrial Disorders Laboratory Database. The mean ages of onset and diagnosis were 43 and 63 years, respectively. Family history was positive in 22 patients. Ptosis and PEO (92\% and $80 \%)$ were the most common findings. Weakness was present in $48 \%$, affecting proximal limbs, neck, and bulbar muscles. Exercise intolerance was present in $28 \%$. Less frequent manifestations were cardiac (24\%) and respiratory $(4 \%)$ involvement, neuropathy $(8 \%)$, ataxia $(4 \%)$, and parkinsonism $(4 \%)$. Only $28 \%$ had mild hyperCKemia. All 19 available muscle biopsies showed signs of mitochondrial dysfunction. Ten different TWNK mutations were identified, with c.1361T>G (p.Val454Gly) and c.1070G >C (p.Arg357Pro) being the most common. Before definitive genetic confirmation, $56 \%$ of patients were misdiagnosed ( $36 \%$ with myasthenia, 20\% with oculopharyngeal muscle dystrophy). Accurate differential diagnosis and early confirmation with appropriately chosen complementary studies allow genetic counseling and the avoidance of unnecessary treatments. Thus, mitochondrial myopathies must be considered in PEO/PEO-plus presentations, and particularly, TWNK is an important cause when positive family history is present.
\end{abstract}

Keywords: TWNK gene; mitochondrial dysfunction; mtDNA maintenance defects; progressive external ophthalmoplegia 


\section{Introduction}

Genetic mitochondrial diseases can result from mitochondrial DNA (mtDNA) mutations or from nuclear DNA mutations. Some of the nuclear genes are involved in mtDNA replication and synthesis, and its alteration causes the so-called mitochondrial DNA maintenance defects. The genes in this group encode proteins that play a critical role in different processes: mtDNA replication (POLG, POLG2, TWNK, TFAM, RNASEH1, MGME1, DNA2), maintenance of a balanced mitochondrial nucleotide pool (TK2, DGUOK. SUCLG1, SUCLA2, ABAT, RRM2B, TYMP, SLC25A4, AGK, MPV17), and regulation of mitochondrial dynamics (OPA1, MFN2, FBXL4) [1]. Pathogenic mutations in these genes can result in a broad clinical spectrum ranging from severe early-onset disorders to milder presentations with later onset, and are typically linked to the presence of mtDNA depletions and/or multiple mtDNA deletions [1,2].

The TWNK gene encodes a replicative mtDNA helicase, thus playing a critical role in the mtDNA replisome. Pathogenic mutations impair its helicase activity and result in replication stalling and impaired mtDNA synthesis [1-3].

Autosomal recessive TWNK mutations have been linked to infantile-onset spinocerebellar ataxia (IOSCA) and hepatocerebral depletion disorder, whereas dominant TWNK mutations are characterized by progressive external ophthalmoplegia (PEO) and ptosis in most patients, typically with an adult-onset presentation. In the latter cases, muscle pathology is associated with multiple mtDNA deletions [1,4]. Although pure-PEO presentations are common, other additional clinical features may be found, such as muscle weakness, exercise intolerance, fatigue, bulbar symptoms, and less frequent cardiac or respiratory involvement, ataxia, neuropathy, cataracts, and parkinsonism, among others [1,4-6].

In this study, we summarize the clinical, pathological, and genetic features of 25 patients with confirmed heterozygous mutations in TWNK recruited from the Hospital 12 de Octubre Mitochondrial Disorders Laboratory Database, report two novel mutations, and provide a guide for differential diagnosis in clinical practice.

\section{Materials and Methods}

\subsection{Patients and Data}

The 25 study subjects were recruited retrospectively from the database of the Mitochondrial and Neuromuscular Disorders Laboratory of the Hospital Universitario 12 de Octubre in Madrid, a national reference center of rare neuromuscular diseases in Spain. All the patients included in this series were adult patients referred for clinical and/or molecular assessment due to suspected mitochondrial myopathy, identifying pathogenic or likely pathogenic mutations in the TWNK gene after genetic testing. We included all patients identified in our database up to March 2021. Partial data of some patients $(1,2,9$, $15,19,22,25)$ has been published previously [6]. Written informed consent was obtained according to the Ethics Committee requirements.

Clinical evaluations were performed according to the standard of care and were retrospectively reviewed from clinical records.

Circulating GDF-15 was assessed in serum by a quantitative electrochemiluminescence immunoassay in three patients (Elecsys GDF-15; Roche Diagnostics, Basel, Switzerland).

Brain imaging studies were performed with $\mathrm{CT}$ in one patient (patient 22) and with MRI (1.5T system) in six patients (patients 2, 3, 4, 5, 7, and 9). Muscle MRI studies were obtained in three patients. Electrophysiological studies were available in sixteen patients. Respiratory function tests were performed when the suggestive clinical data of respiratory involvement was present, being available in three patients. Muscle biopsies were obtained in 19 out of 25 patients and were processed for routine histochemical and immunohistochemical analyses. 


\subsection{Genetic Analysis}

Multiple mtDNA deletions were analyzed in skeletal muscle by Southern blot (SB) using mtDNA probes marked with digoxigenin (Roche Diagnostics) and long-range PCR (LR-PCR) of mtDNA using LA Taq DNA Polymerase (Takara Bio, Kusatsu, Japan).

The identification of variants in the TWNK gene was performed using intronic primers [7] by direct Sanger sequencing (ABI 3500 Genetic Analyzer, Applied Biosystems, Warrington, UK) or by using a customized next-generation sequencing (NGS) panel of 13 genes associated with defects in mtDNA maintenance (DGUOK, MFN2, MPV17, OPA1, POLG, POLG2, RRM2B, SLC25A4, SUCLA2, SUCLG1, TK2, TWNK, and TYMP) and sequencing with the PGM-Ion Torrent platform (Life Technologies, Carlsbad, CA, USA). The alignment of the sequences (ref. CRCh37/hg19) and detection of variants was performed in Torrent Suite (TMAP-variant caller plugin). The annotation and prioritization of variants were carried out by our own scripts integration with Annovar.

Variant prioritization was performed assuming an autosomal dominant or recessive inheritance following the next steps: (i) a Minor Allele Frequency (MAF) $<0.5 \%$ in population databases including 1000 Genomes Project [8], Exome Variant Server [9], Genome Aggregation Database (gnomAD) [10], and Collaborative Spanish Variant Server [11]; (ii) intronic variants localized far from 15 nucleotides of the exon/intron junction were discarded; (iii) status and ranking of the variants in the ClinVar database [12]; (iv) variant pathogenicity predictors including Sorting Intolerant from Tolerant (SIFT) [13], PolyPhen-2 [14], MutationTaster [15], Mendelian Clinically Applicable Pathogenicity Score (M-CAP) [16], Protein Variation Effect Analyzer (PROVEAN) [17], and Combined Annotation Dependent Depletion (CADD) Phred [18]; (v) assessment of phylogenetic conservation using Genomic Evolutionary Rate Profiling (GERP) [19], and the Phylogenetic Analysis with Space/Time models (PHAST) programs: phastCons and phyloP [20].

\section{Results}

\subsection{Clinical Features}

The clinical features of the 25 patients from 21 unrelated families are summarized in Table 1 and Figure 1. Sixteen were women (64\%). Symptoms started at adulthood ( $\geq 18$ years old) in 20 patients $(80 \%)$ and at childhood/adolescence in three patients $(12 \%)$, being the age at onset uncertain in the two remaining patients. The mean age at onset was 43 years old. The mean age at genetic diagnosis was 63 years (range 28-86 years). Twenty-two patients had first-degree relatives with ptosis and/or ophthalmoplegia.

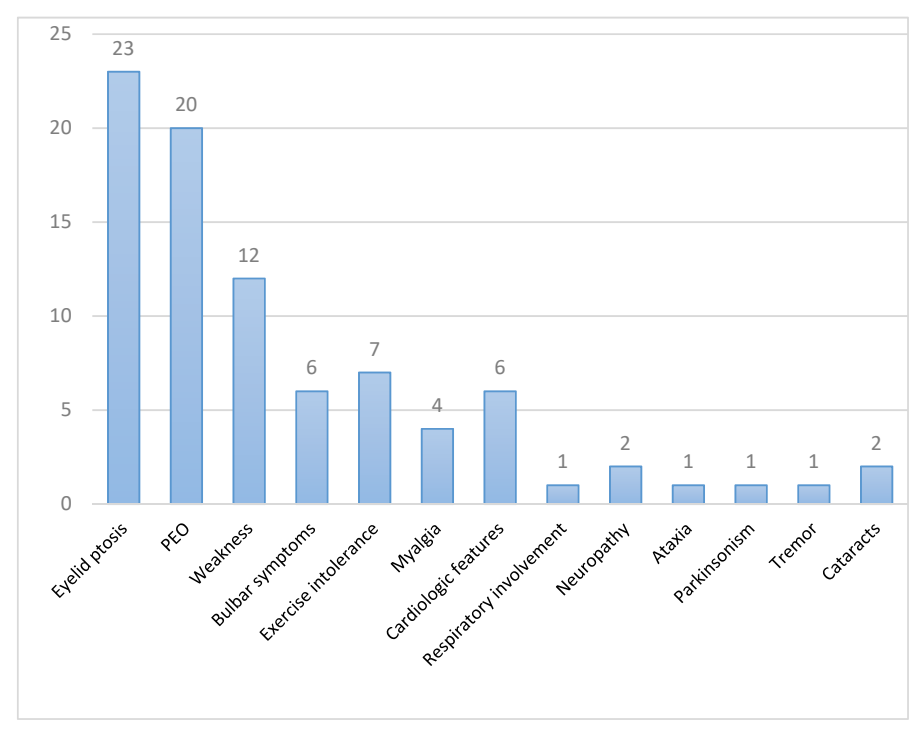

Figure 1. Clinical findings of the 25 patients in our series. Each bar represents the number of patients presenting a specific clinical feature. PEO: progressive external ophthalmoplegia. 
Table 1. Clinical features of patients with autosomal dominant progressive external ophthalmoplegia and TWNK mutations.

\begin{tabular}{|c|c|c|c|c|c|c|c|c|c|c|c|}
\hline Patient & Sex & $\begin{array}{l}\text { Age } \\
\text { (y.o) }\end{array}$ & $\begin{array}{l}\text { Age at } \\
\text { Onset }\end{array}$ & Family History & $\begin{array}{l}\text { Eyelid } \\
\text { Ptosis }\end{array}$ & CPEO & Weakness & Dysarthria/Dysphagia & $\begin{array}{c}\text { Cardiac/Respiratory } \\
\text { Involvement }\end{array}$ & Others & $\begin{array}{c}\text { Previous Diagnosis and } \\
\text { Treatment }\end{array}$ \\
\hline 1 & M & 65 & 30 & $\begin{array}{l}\text { Yes. } \\
\text { Nephew of } \\
\text { pt. } 23\end{array}$ & Yes & Yes & $\begin{array}{l}\text { Inferior facial, } \\
\text { mild cervical, } \\
\text { proximal UL } \\
\text { and LL }\end{array}$ & Dysarthria and dysphagia & $\begin{array}{c}\text { No suggestive clinical } \\
\text { data; normal ECG, } \\
\text { FVC } 105 \%\end{array}$ & No & OPMD; no treatment \\
\hline 2 & $\mathrm{~F}$ & 74 & Adult & Yes & Yes & Yes & No & No & $\begin{array}{l}\text { Tachycardia under study, } \\
\text { ECG: LAFB }\end{array}$ & No & $\begin{array}{c}\text { Seronegative ocular MG, } \\
\text { no treatment }\end{array}$ \\
\hline 3 & M & 82 & 40 & $\begin{array}{c}\text { Yes } \\
\text { Brother of pt. } 7\end{array}$ & Yes & Yes & $\begin{array}{l}\text { Mild cervical, } \\
\text { mild proximal } \\
\text { UL and LL }\end{array}$ & No & $\begin{array}{l}\text { No suggestive } \\
\text { clinical data }\end{array}$ & $\begin{array}{l}\text { Exercise intolerance, } \\
\text { ataxia, PNP }\end{array}$ & $\begin{array}{l}\text { Seronegative MG; } \\
\text { pyridostigmine (NR) }\end{array}$ \\
\hline 5 & M & 28 & 17 & No & Yes & Yes & No & No & $\begin{array}{l}\text { Palpitations with normal } \\
\text { TTE and Holter-ECG }\end{array}$ & $\begin{array}{l}\text { Myalgias, exercise } \\
\text { intolerance, } \\
\text { subclinical PNP }\end{array}$ & $\begin{array}{l}\text { Seronegative MG; } \\
\text { no treatment }\end{array}$ \\
\hline 6 & $\mathrm{~F}$ & 64 & 60 & Yes & Yes & Yes & No & No & $\begin{array}{l}\text { No suggestive } \\
\text { clinical data }\end{array}$ & $\begin{array}{l}\text { Episodes of acute } \\
\text { worsening with bulbar } \\
\text { and limb weakness }\end{array}$ & $\begin{array}{c}\text { Seronegative MG; } \\
\text { pyridostigmine (NR), } \\
\text { acute episodes: IVIg, } \\
\text { plasma exchange, IS (NR) }\end{array}$ \\
\hline 7 & $\mathrm{~F}$ & 86 & 60 & $\begin{array}{c}\text { Yes } \\
\text { Sister of pt. } 3\end{array}$ & Yes & No & Mild proximal LL & No & $\begin{array}{l}\text { Suspicion of sleep apnea; } \\
\text { mild LVEF reduction }\end{array}$ & $\begin{array}{l}\text { Essential tremor (UL, } \\
\text { head and jaw), } \\
\text { exercise intolerance }\end{array}$ & - \\
\hline 8 & M & 68 & 30 & Yes & Yes & Yes & No & No & $\begin{array}{l}\text { No suggestive } \\
\text { clinical data }\end{array}$ & - & - \\
\hline 9 & M & 36 & 25 & No & Yes & Yes & No & No & $\begin{array}{l}\text { No suggestive clinical } \\
\text { data; ECG: RBBB, } \\
\text { normal TTE }\end{array}$ & - & $\begin{array}{l}\text { Seronegative MG, OPMD; } \\
\text { no treatment }\end{array}$ \\
\hline 10 & F & 58 & 50 & Yes & Yes & Yes & No & No & $\begin{array}{l}\text { No suggestive } \\
\text { clinical data }\end{array}$ & - & - \\
\hline 11 & $\mathrm{~F}$ & 59 & 43 & $\begin{array}{l}\text { Sister with } \\
\text { epilepsy. Both } \\
\text { parents dementia }\end{array}$ & No & No & $\begin{array}{l}\text { Mild cervical, } \\
\text { mild proximal } \\
\text { UL and LL }\end{array}$ & No & $\begin{array}{l}\text { No suggestive } \\
\text { clinical data }\end{array}$ & $\begin{array}{l}\text { Generalized myalgias at } \\
\text { rest, cramps with statins } \\
\text { in the past, } \\
\text { exercise intolerance }\end{array}$ & - \\
\hline 12 & M & 67 & Adult onset & Yes & Yes & Yes & No & No & $\begin{array}{l}\text { No suggestive } \\
\text { clinical data }\end{array}$ & - & OPMD; no treatment. \\
\hline 13 & $\mathrm{~F}$ & 72 & 40 & Yes & Yes & No & Mild cervical & Dysphagia & $\begin{array}{l}\text { No suggestive } \\
\text { clinical data }\end{array}$ & - & OPMD, no treatment \\
\hline
\end{tabular}


Table 1. Cont.

\begin{tabular}{|c|c|c|c|c|c|c|c|c|c|c|c|}
\hline Patient & Sex & $\begin{array}{l}\text { Age } \\
\text { (y.o) }\end{array}$ & $\begin{array}{l}\text { Age at } \\
\text { Onset }\end{array}$ & Family History & $\begin{array}{l}\text { Eyelid } \\
\text { Ptosis }\end{array}$ & CPEO & Weakness & Dysarthria/Dysphagia & $\begin{array}{l}\text { Cardiac/Respiratory } \\
\text { Involvement }\end{array}$ & Others & $\begin{array}{c}\text { Previous Diagnosis and } \\
\text { Treatment }\end{array}$ \\
\hline 14 & $\mathrm{M}$ & 54 & 40 & Yes & Yes & No & No & No & $\begin{array}{l}\text { No suggestive } \\
\text { clinical data }\end{array}$ & - & Seronegative MG. \\
\hline 15 & $\mathrm{~F}$ & 51 & $\begin{array}{c}\text { Not } \\
\text { reported }\end{array}$ & Yes & No & Yes & No & No & $\begin{array}{l}\text { No suggestive } \\
\text { clinical data }\end{array}$ & - & Seronegative MG \\
\hline 16 & $\mathrm{~F}$ & 67 & Adult onset & Yes & Yes & Yes & $\begin{array}{l}\text { Proximal UL } \\
\text { and LL }\end{array}$ & No & $\begin{array}{l}\text { No suggestive } \\
\text { clinical data }\end{array}$ & - & OPMD; no treatment. \\
\hline 17 & $\mathrm{~F}$ & 32 & $\begin{array}{l}\text { Not } \\
\text { reported }\end{array}$ & Yes & Yes & Yes & $\begin{array}{l}\text { Cervical, } \\
\text { proximal UL } \\
\text { and LL }\end{array}$ & No & $\begin{array}{l}\text { No suggestive } \\
\text { clinical data }\end{array}$ & Exercise intolerance & - \\
\hline 18 & $\mathrm{~F}$ & 49 & 14 & Yes & Yes & Yes & $\begin{array}{c}\text { Cervical, } \\
\text { proximal and } \\
\text { distal UL and LL }\end{array}$ & Dysphagia & $\begin{array}{l}\text { No suggestive } \\
\text { clinical data }\end{array}$ & - & - \\
\hline 19 & $\mathrm{~F}$ & 44 & $\begin{array}{l}\text { Childhood } \\
\text { onset }\end{array}$ & Yes & Yes & Yes & No & No & $\begin{array}{l}\text { No suggestive } \\
\text { clinical data }\end{array}$ & $\begin{array}{l}\text { Occasional cramps; } \\
\text { fatigable ocular } \\
\text { weakness reported }\end{array}$ & Seronegative MG \\
\hline 20 & $\mathrm{~F}$ & 78 & 50 & Yes & Yes & Yes & $\begin{array}{c}\text { Proximal at } \\
\text { limbs }\end{array}$ & No & $\begin{array}{l}\text { No suggestive } \\
\text { clinical data }\end{array}$ & - & - \\
\hline 21 & $\mathrm{M}$ & 80 & 45 & $\begin{array}{c}\text { Yes } \\
\text { Brother of pt. } 22\end{array}$ & Yes & Yes & $\begin{array}{l}\text { Orbicularis } \\
\text { oculi, inferior } \\
\text { facial, cervical, } \\
\text { proximal at } \\
\text { limbs }\end{array}$ & Dysarthria and dysphagia & $\begin{array}{l}\text { No suggestive clinical } \\
\text { data; FVC } 100.9 \% \text {; } \\
\text { mild LVH }\end{array}$ & $\begin{array}{l}\text { Myalgias, exercise } \\
\text { intolerance }\end{array}$ & - \\
\hline 22 & $\mathrm{~F}$ & 80 & 40 & $\begin{array}{c}\text { Yes } \\
\text { Sister of pt. } 21\end{array}$ & Yes & Yes & $\begin{array}{c}\text { Orbicularis } \\
\text { oculi, cervical, } \\
\text { limbs }\end{array}$ & Dysphagia & FVC $57 \%$ & Parkinsonism & - \\
\hline 23 & $\mathrm{~F}$ & 82 & 60 & $\begin{array}{c}\text { Yes } \\
\text { Aunt of pt. } 1\end{array}$ & Yes & No & No & No & Not reported & - & - \\
\hline 24 & $\mathrm{M}$ & 55 & 48 & $\begin{array}{c}\text { Yes } \\
\text { Son of pt. } 25\end{array}$ & Yes & Yes & No & No & Not reported & Cataracts 48 y.o & - \\
\hline 25 & $\mathrm{~F}$ & 76 & 64 & $\begin{array}{c}\text { Yes } \\
\text { Mother of pt. } 24\end{array}$ & Yes & Yes & No & No & Not reported & Cataracts 50 y.o & - \\
\hline
\end{tabular}

CPEO: chronic progressive external ophthalmoplegia; ECG: electrocardiogram; ENG: electroneurography; FVC: forced vital capacity; GC: glucocorticoids; IS: immunosuppression IVIg: intravenous immunoglobulins; MG: myasthenia gravis; LAFB: left anterior fascicular block; LL: lower limbs; LVEF: left ventricular ejection fraction; LVH: left ventricular hypertrophy; NR: no response; OPMD: oculopharyngeal muscular dystrophy; PNP: polyneuropathy; RBBB: right bundle branch block; RI: respiratory insufficiency; TTE: transthoracic echocardiography; UL: upper limbs; y.o: years old. 
The most frequent clinical features in our series were ptosis ( 23 out of $25,92 \%$ ) and PEO (20 out of $25,80 \%$ ). Five patients reported fluctuating diplopia. Weakness was present in 12 patients (48\%), especially affecting the limbs in $11(44 \%)$ patients and the cervical region in 9 patients (36\%). Limb weakness was proximal in all cases, with additional distal weakness in one patient; distal weakness without proximal involvement was not reported. Its degree was mild, with no muscular atrophy in any case. Facial weakness was observed in three patients. Seven patients described exercise intolerance $(28 \%)$, of whom four also presented myalgias (16\%). Occasional muscle cramps were reported by two patients, being in one of them concurrent with statin intake and resolved after drug cessation.

Six patients had bulbar involvement (dysphagia and/or dysarthria) (24\%), although no patient required enteral nutrition.

Cardiologic abnormalities were observed in six patients $(24 \%)$, being all mild and unspecific (see Table 1). Similar findings have been reported previously among patients with TWNK mutations [4].

Patients with respiratory symptoms were further tested for respiratory muscle dysfunction, confirming in one patient a reduction of the forced vital capacity (FVC) of 57\%, and another was eventually diagnosed with obstructive sleep apnea.

Two patients presented features suggestive of polyneuropathy (8\%): a 28-year-old man (patient 5) with mildly reduced SNAP amplitude in lower limbs, although asymptomatic, and patient 3 with a highly suggestive clinical picture without electrophysiological tests performed. This latter patient also presented gait ataxia which made walking aid necessary.

Other less common findings observed were parkinsonism and essential tremor, found in one patient each, and two related patients (24 and 25) developed cataracts at the ages of 48 and 50 years with no other known associated risk factors.

Based on the clinical phenotype at initial evaluations, nine patients (36\%) were initially misdiagnosed as seronegative myasthenia gravis due to the ocular findings despite the lack of fatigability on examination or other supportive paraclinical data. Three of them, who associated extraocular symptoms, received specific treatment for myasthenia gravis (see Table 1) with no clinical improvement.

Another frequently considered alternative diagnosis before confirmation of TWNK mutations was oculopharyngeal muscular dystrophy (OPMD) in five patients (20\%).

\subsection{Complementary Tests}

All tests were assessed as standard-of-care clinical procedures. From 18/25 patients with available data, $5 / 18$ patients showed CK levels above the upper limit of the reference $(28 \%)$, with a mean value of $278 \mathrm{U} / \mathrm{L}$.

Markers related to mitochondrial dysfunction were also studied, such as lactate and the more specific and sensitive GDF-15, the latter only recently available in our center. Mild hyperlactacidemia was found in three out of six tested patients (3.24-3.7 mmol/L). Serum GDF-15 levels could be determined only in 3/25 patients, being elevated in two $(1454 \mathrm{pg} / \mathrm{mL}$ in patient 5 and $2727 \mathrm{pg} / \mathrm{mL}$ in patient 6) and normal in one $(991 \mathrm{pg} / \mathrm{mL}$ in patient 2). Results were adjusted according to age. Patient 2, unlike the others, did not have clinical data of muscular involvement additional to PEO.

Electrophysiologic testing, performed in 15/25 patients, showed myopathic features on needle EMG testing in nine $(60 \%)$, neurogenic features in nerve conduction studies and needle EMG in two (13\%), and was normal in four patients $(27 \%)$.

Muscle MRI was performed in 3/25 patients with extraocular complaints, with normal results in one patient and an unspecific pattern of muscle edema and fatty infiltration in the other two (see Table 2). Brain imaging (MRI or CT) was performed in 7/25 patients, with normal results or mild incidental findings displayed in all of them. 
Table 2. Complementary studies.

\begin{tabular}{|c|c|c|c|c|c|c|c|c|c|}
\hline Patient & CK (IU/L) & $\begin{array}{c}\text { Lactate } \\
(\mathrm{mmol} / \mathrm{L})\end{array}$ & GDF15 (pg/mL) & EMG/ENG & Muscle MRI & Muscle Biopsy & TWNK Variant & Protein Change & $\begin{array}{c}\text { Multiple mtDNA } \\
\text { Deletions } \\
\text { (Skeletal Muscle) }\end{array}$ \\
\hline 1 & 300 & - & - & - & - & - & c. $1361 \mathrm{~T}>\mathrm{G}$ & p.Val454Gly & - \\
\hline 2 & & & 990.6 & Normal & & RRF and COX negative fibers & c.1070G >C & p.Arg357Pro & $\mathrm{Y}$ \\
\hline 3 & 68 & 3.7 & - & - & - & - & c. $1070 \mathrm{G}>\mathrm{C}$ & p.Arg357Pro & - \\
\hline 4 & 21 & - & - & Normal & $\begin{array}{l}\text { IL: diffuse edema of } \\
\text { both gastrocnemius } \\
\text { and lateral and distal } \\
\text { portion of left soleus }\end{array}$ & $\begin{array}{l}\text { Frequent RBF, } 1 \% \text { COX } \\
\text { negative fibers }\end{array}$ & c. $1070 \mathrm{G}>\mathrm{C}$ & p.Arg357Pro & Y \\
\hline 6 & 37 & - & 2727 & - & - & RRFs and $1 \%$ COX negative fibers. & c. $1361 \mathrm{~T}>\mathrm{G}$ & p.Val454Gly & - \\
\hline 7 & 300 & - & - & Myopathic & - & $\begin{array}{l}\text { RRF, COX negative fibers, complex } \\
\text { IV deficiency }\end{array}$ & c. $1070 \mathrm{G}>\mathrm{C}$ & p.Arg357Pro & Y \\
\hline 8 & Normal & - & - & Myopathic & - & Occasional RRF & c. $1361 \mathrm{~T}>\mathrm{G}$ & p.Val454Gly & $\mathrm{Y}$ \\
\hline 9 & 305 & Normal & - & Normal & - & $\begin{array}{l}\text { Frequent RBF (most of them COX } \\
\text { negative, } 3.5 \% \text { of total fibers) }\end{array}$ & c. $1121 \mathrm{G}>\mathrm{A}$ & p.Arg374Gln & $\mathrm{Y}$ \\
\hline 10 & - & - & - & - & - & - & c. $1361 \mathrm{~T}>\mathrm{G}$ & p.Val454Gly & - \\
\hline 12 & - & - & - & $\begin{array}{l}\text { Moderate myopathic } \\
\text { signs }\end{array}$ & - & $\begin{array}{c}\text { Unspecific: isolated RBF, }<1 \% \text { COX } \\
\text { negative fibers }\end{array}$ & c. $908 \mathrm{G}>\mathrm{A}$ & p.Arg303Gln & Y \\
\hline 13 & - & - & - & - & $\begin{array}{c}\text { Diffuse fatty } \\
\text { infiltration of } \\
\text { paravertebral } \\
\text { muscles, abnormal } \\
\text { signal at both } \\
\text { serratus anterior }\end{array}$ & $\begin{array}{l}\text { RRF and frequent } C O X \\
\text { negative fibers }\end{array}$ & $\begin{array}{c}\text { c.1106C }>\mathrm{T} \\
\text { (new description) }\end{array}$ & p.Ser369Phe & $\mathrm{Y}$ \\
\hline 14 & 95 & - & - & Myopathic & - & $\begin{array}{l}\text { RRF, } 10 \% \text { COX negative, type } 1 \\
\text { fiber predominance }\end{array}$ & c. $1070 \mathrm{G}>\mathrm{C}$ & p.Arg357Pro & Y \\
\hline 15 & Normal & - & - & - & - & $\begin{array}{c}\text { Occasional RRF, } 2 \% \text { COX } \\
\text { negative fibers }\end{array}$ & c. $1361 \mathrm{~T}>\mathrm{G}$ & p.Val454Gly & Y \\
\hline 16 & 74 & - & - & Myopathic & - & $\begin{array}{l}\text { Unspecific oxidative alterations, } \\
3 \text { RRF }\end{array}$ & c. $1361 \mathrm{~T}>\mathrm{G}$ & p.Val454Gly & $\mathrm{Y}$ \\
\hline
\end{tabular}


Table 2. Cont.

\begin{tabular}{|c|c|c|c|c|c|c|c|c|c|}
\hline Patient & CK (IU/L) & $\begin{array}{c}\text { Lactate } \\
(\mathrm{mmol} / \mathrm{L})\end{array}$ & GDF15 (pg/mL) & EMG/ENG & Muscle MRI & Muscle Biopsy & TWNK Variant & Protein Change & $\begin{array}{c}\text { Multiple mtDNA } \\
\text { Deletions } \\
\text { (Skeletal Muscle) }\end{array}$ \\
\hline 17 & - & - & - & - & - & $\begin{array}{l}\text { RRF, frequent COX negative fibers, } \\
\text { some internal nuclei }\end{array}$ & c. $1121 \mathrm{G}>\mathrm{A}$ & p.Arg374Gln & Y \\
\hline 19 & 312 & - & - & Myopathic & - & $3 \%$ COX negative fibers & c.1084G>C & p.Arg362Pro & $\mathrm{Y}$ \\
\hline 20 & Normal & Normal & - & Myopathic & - & RRF and COX negative fibers & c. $1071 \mathrm{G}>\mathrm{C}$ & p.Arg357Pro & Y \\
\hline 21 & 113 & Raised & - & Myopathic & - & $\begin{array}{l}\text { RRF, massive mitochondrial } \\
\text { accumulations with SDH, loss of } \\
\text { COX activity. Complex I and } \\
\text { IV deficiency }\end{array}$ & c. $1411 \mathrm{~T}>\mathrm{G}$ & p.Tyr471Asp & Y \\
\hline 22 & 66 & - & - & - & - & - & c. $1411 \mathrm{~T}>\mathrm{G}$ & p.Tyr471Asp & - \\
\hline 23 & 54 & - & - & Myopathic & - & RRF, type 1 fiber predominance & c. $1361 \mathrm{~T}>\mathrm{G}$ & p.Val454Gly & - \\
\hline 24 & - & - & - & - & - & - & c. $1070 \mathrm{G}>\mathrm{C}$ & p.Arg357Pro & - \\
\hline 25 & 61 & 3.24 & - & Normal ENG & - & RRF & c.1070G $>C$ & p.Arg357Pro & $\mathrm{Y}$ \\
\hline
\end{tabular}

NA: not available; RBF: ragged blue fibers; RRF: ragged red fibers; SVD: small vessel disease; Y: Yes; -: not performed or not data recorded. 
Muscle biopsy was available in 19/25 patients, with signs of mitochondrial dysfunction (RRF or COX-negative fibers) presenting in all of them. Four patients who did not undergo biopsy were relatives of others with confirmed TWNK mutations.

Multiple mtDNA deletions were found in the skeletal muscle of all patients tested (17/17).

\subsection{Genetic Results}

Ten different mutations in the TWNK gene were identified, all of them being heterozygous missense variants clustered in exons 1 and 2 . The most frequent mutations identified in our series were c.1361T>G (p.Val454Gly), found in seven patients from six families, and c.1070G >C (p.Arg357Pro), identified in seven patients from five families (see Table 2). Other TWNK mutations identified were c.1121G>A (p.Arg374Gln) in three unrelated patients (12\%), c.1411T>G (p.Tyr471Asp) in two siblings (8\%), and c.908G>A (p.Arg303Gln), c.1433T >G (p.Phe478Cys), c.1084G >C (p.Ala362Pro), c.1071G >C (p.Arg357Pro), c.1087T >A (p.Trp363Arg), and c.1106C >T (p.Ser369Phe) in single cases. Figure 2 shows the location of each mutation in the gene.
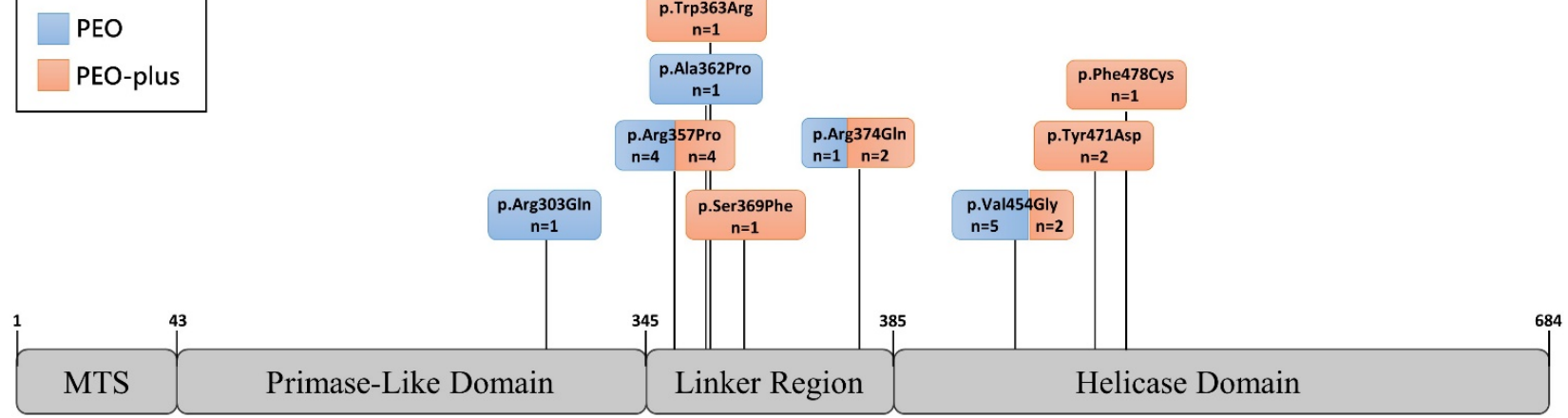

Figure 2. Phenotypic features depending on the affected protein domain. TWNK protein representation showing the distribution of the mutations identified in our cohort along the domains of the protein and the number of patients presenting PEO (blue) or PEO-plus (orange) phenotype for each variant. PEO: progressive external ophthalmoplegia. MTS: mitochondrial targeting sequence. Numbers on the TWNK protein denote the aminoacidic residue delimiting the domains.

The last two have not been previously reported. Similarly to other known mutations, both are missense variants located at exon 1 of the TWNK gene, and affect linker region in the protein product $[2,4]$. They are predicted to be pathogenic according to ACMG classification [21], as they both fulfil three criteria of moderate pathogenicity, which are: (1) occurrence at a mutational hot spot, (2) absence from control subjects in Genome Aggregation Database (gnomAD), Exome Sequencing Project, or 1000 Genomes Project, and (3) being a missense change at an amino acid residue where a different pathogenic missense changes have already been identified before, such as c.1088G >T (p.Trp363Leu), c.1105T>C (p.Ser369Pro), and c.1106C >A (p.Ser369Tyr) [21]. Additional supportive evidence for their pathogenicity is the low rate of benign missense variants in the TWNK gene, and in the case of c.1106C > T the presence of multiple predictors supporting a deleterious effect (such as Bayes Del_addAF, DANN, DEOGEN2, EIGEN, FATHMM-MKL, LIST-S2, M-CAP, MVP, Mutation Assessor, MutationTaster and SIFT, with no benign predictions).

\section{Discussion}

Our study describes the clinical and molecular characteristics of 25 adult patients with genetically confirmed autosomal dominant TWNK mutations.

The predominant clinical features among our patients were ptosis (92\%) and PEO (80\%). This is consistent with descriptions in previous works about TWNK-related adPEO, where PEO and ptosis are almost universal findings [1,4,5,7], with ptosis often being the first sign and preceding the ocular weakness [5,22]. 
The presence of PEO has been identified as a clinical hallmark of mtDNA disorders since the earliest clinical descriptions of mitochondrial syndromes [22,23], which was confirmed by subsequent studies. In this sense, the most frequent underlying defects in PEO patients are sporadic single large-scale mtDNA deletions [6,22], followed by mutations in mtDNA maintenance nuclear genes, which are the most common genetic finding when positive family history is present $[6,23]$. Recent series of PEO patients state that among these latter disorders, POLG and TWNK mutations are the most frequently involved nuclear genes with a similar rate of occurrence $[6,24]$. Although, in general terms, POLG has been commonly linked to a PEO-plus phenotype and TWNK to pure-PEO $[1,4,6]$, additional associated features in TWNK patients are not rare, being the PEO-plus phenotype more common in our cohort, as in some other previously reported works [5].

The presence of associated proximal muscle weakness is common in all series published to date, ranging between 30 and 80\% [3-5]. Other possible associated symptoms described in the literature include bulbar symptoms (12-31\%), respiratory involvement (17\%), cardiological abnormalities (11-24\%), polyneuropathy (15-40\%), ataxia (9\%), parkinsonism, and tremor $(13 \%)$, and less frequently cataracts, visual disturbances and sensorineural hearing loss. All of them were present in our series in a similar frequency [3-5].

With respect to cardiac manifestations, it has been proposed that myocardial involvement and arrhythmias could be part of the TWNK phenotype [4]. We also found unspecific and mild cardiac abnormalities in about a quarter of our patients, but it is unclear if TWNK mutations play a causative role in their development.

Regarding the diagnostic approach, it is worth noting that although not in all cases, while myopathic changes were identified in the electrophysiological studies, it did allow us to rule out signs of alteration of the neuromuscular junction, supporting its utility in the differential diagnosis in patients with ocular symptoms. On the other hand, plasma $\mathrm{CK}$ and lactate levels found in our series would fit in the previously reported ranges of hyperCKemia and hyperlactacidemia in patients with mitochondrial myopathy [3,6,23]. Thus, CK levels in patients harboring TWNK mutations are typically normal or only slightly elevated. An exception among mitochondrial myopathies is a TK2 deficiency, where hyperCKemia is common and typically 10-fold above the upper normal limit (up to 30-fold) [25-27]. Therefore, these two parameters lack enough sensitivity and specificity for the diagnosis of mitochondrial diseases [22,26,28]. Although GDF15 serum levels seem to provide a better prediction of mitochondrial disease regardless of clinical phenotype (with a diagnostic sensitivity of around 80\% [28-30]), the small number of patients evaluated in our series prevents us from drawing conclusions about its diagnostic performance in patients with PEO syndrome. Finally, when a muscle biopsy was performed, it allowed guiding the genetic study in all cases, since signs of mitochondrial dysfunction and mtDNA multiple deletions were found in all of them.

Of the over 40 known adPEO-causing TWNK mutations, almost all are missense changes, occurring throughout the entire length of the gene but clustering at exons 1 and 2, specially affecting the primase-like and linker region protein domains $[2,4,24]$. Our findings are consistent with this, with the two novel likely pathogenic identified variants, c.1087T $>\mathrm{A}$ (p.Trp363Arg) and c.1106C>T (p.Ser369Phe), being missense changes located at exon 1 in the linker region. In our cohort, we did not identify phenotype-genotype correlations since the phenotype did not depend on the affected protein domain (see Figure 2).

Among our patients, we observed frequent misdiagnosis in the form of seronegative myasthenia gravis and OPMD, which should be kept in mind for the differential diagnosis, as they can present with similar clinical findings.

Autoimmune myasthenia gravis with prominent ocular involvement may be confused with PEO, although its clinical presentation and course are different: myasthenia presentation is typically acute or subacute, with marked diurnal fluctuations and fatigability, and variable measurements on examination. On the other hand, PEO presents typically with chronic and more constant findings. Although PEO may show subtle eyelid fatigability, marked fatigue on prolonged maintenance of a certain position or highly variable mea- 
surements on a given examination strongly supports the diagnosis of myasthenia gravis. The same applies to muscular weakness at limbs and other territories [22]. Furthermore, additional neurological features possibly associated to TWNK phenotype, as well as the existence of positive family history, are absent in autoimmune myasthenia. In those cases where the clinical picture does not allow clear distinction, an electrophysiologic test, serum antibodies determination and a treatment trial may help, bearing in mind that an absolute lack of response to prednisone suggests an alternative diagnosis other than myasthenia gravis. However, single-fiber EMG can be confusing, as CPEO in mitochondrial myopathies may also show an abnormal jitter [22,31].

Differentiation from congenital myasthenic syndromes can be more challenging. These are very rare inherited diseases caused by mutations in genes encoding for different proteins expressed at the neuromuscular junction that present with a widely heterogeneous clinical picture. Typically, they start within the first years of life with fatigable weakness most commonly ocular and other cranial muscles, as well as limbs and respiratory muscles, with different patterns and severity $[32,33]$. However, there are some cases that are easier to confuse with mitochondrial myopathies due to the existence of fixed weakness and a lack of clear fatigability upon examination. In some cases, there may even be an increase in plasma CK levels and negative COX fibers in the muscle biopsy. [34]. In these cases, a key finding for diagnosis is the presence of abnormal repetitive stimulation in the electrophysiological test, which is not seen in mitochondrial myopathies [31]. Genetic confirmation will provide the definitive diagnosis.

OPMD is a dominantly inherited disorder caused by the expansion of GCN triplets in the PABPN1 gene, usually with a late onset throughout the fifth or sixth decade of life. It initially presents with ptosis and dysphagia and, as the disease progresses, it can affect other muscles, mainly the proximal limb muscles [35]. For the differential diagnosis with mitochondrial myopathies, a muscle biopsy can be helpful showing dystrophic changes and rimmed vacuoles, although some can associate slight mitochondrial alterations [36]. Importantly, muscle MRI has also been proven useful, as OPMD has a characteristic pattern of muscle involvement consisting of an early combination of fat replacement in the tongue, adductor magnus, and soleus [37]. Performing it early in the diagnostic process can help direct genetic testing and avoid muscle biopsy.

We propose the following approach for the differential diagnosis of patients manifesting with chronic PEO (see algorithm in Figure 3): in addition to a conventional EMG, it would be of interest to perform a repetitive nerve stimulation test in patients with suspicion of a neuromuscular junction disorder, because it has a high positive predictive value. However, its sensitivity is around $70 \%$ in generalized myasthenia, and notably lower in ocular myasthenia (20-50\%) [38], in which an ice pack test and a treatment trial may help to confirm the diagnosis if fatigability is found on examination. When a muscle disorder is suspected, a muscle biopsy (which could be obtained with a minimally invasive procedure, such as a needle biopsy) allows us to guide genetic diagnosis (ragged-red COX negative fibers vs. rimmed vacuoles and dystrophic changes in mitochondrial myopathies and OPMD respectively), but also to obtain muscle mitochondrial DNA and look for single or multiple mtDNA deletions, thus identifying primary mtDNA disorders and allowing a more precise selection of patients for additional nuclear DNA analysis when necessary. In patients with limb weakness, prior to muscle biopsy, a muscle MRI can distinguish patients with OPMD who will be diagnosed with targeted analysis of the PABPN1 gene. 


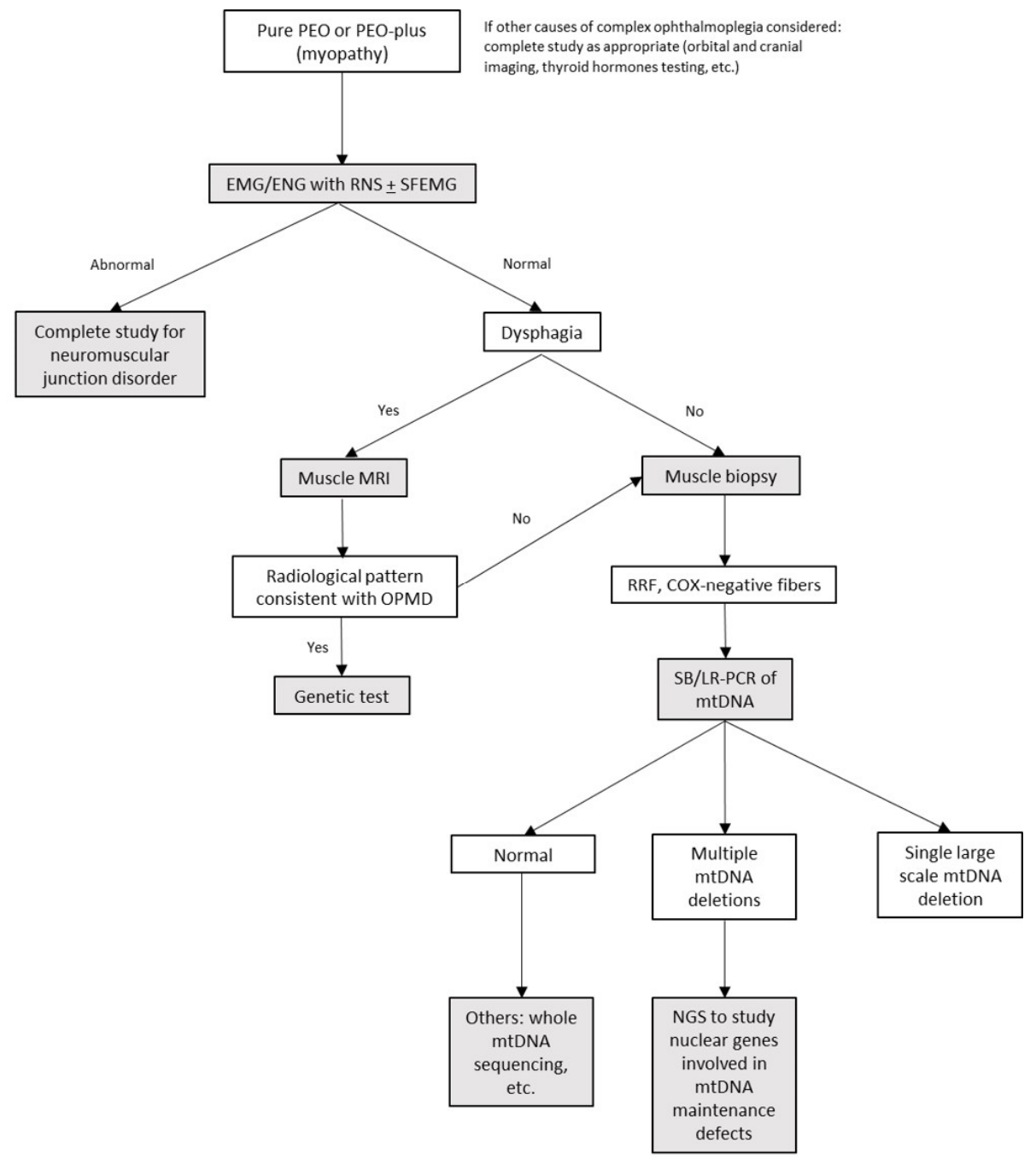

Figure 3. Proposed algorithm for differential diagnosis. Abbreviations: LR-PCR: long-range Polymerase Chain Reaction, NGS: next generation sequencing, RNS: repetitive nerve stimulation, SB: southern blot, SFEMG: single-fiber electromyography.

\section{Conclusions}

This work provides a detailed description of the clinical and paraclinical characteristics of patients with dominant TWNK mutations manifesting with PEO phenotype. We also provide a differential diagnosis approach to minimize the diagnostic odyssey and avoid unnecessary and potentially harmful treatments in these patients.

Author Contributions: Conceptualization, L.B.-G., C.P.d.F.-F.d.l.H., P.S.-L., A.B.-E., G.G.-G., L.M.-V., L.G.-D., J.G.-G., J.A., N.M., A.H.-L., C.D.-G., and M.A.M.; methodology, L.B.-G., C.D.-G., P.S.-L., and M.A.M.; software, L.B.-G., C.P.d.F.-F.d.l.H., P.S.-L., C.D.-G. and M.A.M.; formal analysis, L.B.-G., C.P.d.F.-F.d.1.H., P.S.-L., C.D.-G., and M.A.M.; investigation, L.B.-G., C.P.d.F.-F.d.1.H., P.S.-L., A.B.-E., G.G.-G., L.M.-V., L.G.-D., J.G.-G., J.A., N.M., A.H.-L., C.D.-G., and M.A.M.; data curation, L.B.-G., P.S.L., C.D.-G., and M.A.M.; writing-original draft preparation, L.B.-G.; writing-review and editing, L.B.-G., C.P.d.F.-F.d.l.H., P.S.-L., A.B.-E., G.G.-G., L.M.-V., L.G.-D., J.G.-G., J.A., N.M., A.H.-L., C.D.-G., and M.A.M.; visualization, L.B.-G. and C.D.-G.; supervision, C.D.-G.; project administration, C.D.-G.; funding acquisition, C.D.-G. and M.A.M. All authors have read and agreed to the published version of the manuscript.

Funding: This research was funded by the Ministry of Science and Innovation (Madrid, Spain), supporting a Spanish collaborative grant (PMP15_00025) to M.A.M. Also Grant PI18/01374 to M.A.M. from the 'Instituto de Salud Carlos III' (ISCIII), Spain (co-funded by European Regional Development Fund "A way to make Europe"). P.S.-L. holds a research contract from CIBERER, ISCIII. 
Institutional Review Board Statement: The study was conducted according to the guidelines of the Declaration of Helsinki and to the Hospital 12 de Octubre Ethics Committee requirements.

Informed Consent Statement: Informed consent was obtained from all subjects involved in the study.

Data Availability Statement: The datasets analyzed during the current study are available from the corresponding author upon reasonable request.

Acknowledgments: We are grateful to Pilar del Hoyo and Ericka J. Canlas for their technical support and Aitor Delmiro for his bioinformatic assistance.

Conflicts of Interest: The authors declare no conflict of interest.

\section{References}

1. El-Hattab, A.W.; Craigen, W.J.; Scaglia, F. Mitochondrial DNA Maintenance Defects. Biochim. Biophys. Acta (BBA) Mol. Basis Dis. 2017, 1863, 1539-1555. [CrossRef]

2. Peter, B.; Falkenberg, M. TWINKLE and Other Human Mitochondrial DNA Helicases: Structure, Function and Disease. Genes 2020, 11, 408. [CrossRef]

3. Van Hove, J.L.K.; Cunningham, V.; Rice, C.; Ringel, S.P.; Zhang, Q.; Chou, P.-C.; Truong, C.K.; Wong, L.-J.C. Finding Twinkle in the Eyes of a 71-Year-Old Lady: A Case Report and Review of the Genotypic and Phenotypic Spectrum of TWINKLE-Related Dominant Disease. Am. J. Med. Genet. 2009, 149A, 861-867. [CrossRef]

4. $\quad$ Fratter, C.; Gorman, G.S.; Stewart, J.D.; Buddles, M.; Smith, C.; Evans, J.; Seller, A.; Poulton, J.; Roberts, M.; Hanna, M.G.; et al. The Clinical, Histochemical, and Molecular Spectrum of PEO1 (Twinkle)-Linked AdPEO. Neurology 2010, 74, 1619-1626. [CrossRef]

5. Martin-Negrier, M.-L.; Sole, G.; Jardel, C.; Vital, C.; Ferrer, X.; Vital, A. TWINKLE Gene Mutation: Report of a French Family with an Autosomal Dominant Progressive External Ophthalmoplegia and Literature Review: Twinkle Gene Mutation. Eur. J. Neurol. 2011, 18, 436-441. [CrossRef] [PubMed]

6. Rodríguez-López, C.; García-Cárdaba, L.M.; Blázquez, A.; Serrano-Lorenzo, P.; Gutiérrez-Gutiérrez, G.; San Millán-Tejado, B.; Muelas, N.; Hernández-Laín, A.; Vílchez, J.J.; Gutiérrez-Rivas, E.; et al. Clinical, Pathological and Genetic Spectrum in 89 Cases of Mitochondrial Progressive External Ophthalmoplegia. J. Med. Genet. 2020, 57, 643-646. [CrossRef]

7. Rivera, H.; Blázquez, A.; Carretero, J.; Alvarez-Cermeño, J.C.; Campos, Y.; Cabello, A.; Gonzalez-Vioque, E.; Borstein, B.; Garesse, R.; Arenas, J.; et al. Mild Ocular Myopathy Associated with a Novel Mutation in Mitochondrial Twinkle Helicase. Neuromuscul. Disord. 2007, 17, 677-680. [CrossRef]

8. Clarke, L.; Fairley, S.; Zheng-Bradley, X.; Streeter, I.; Perry, E.; Lowy, E.; Tassé, A.-M.; Flicek, P. The International Genome Sample Resource (IGSR): A Worldwide Collection of Genome Variation Incorporating the 1000 Genomes Project Data. Nucleic Acids Res. 2017, 45, D854-D859. [CrossRef] [PubMed]

9. Exome Variant Server. Available online: https:/ / evs.gs.washington.edu/EVS/ (accessed on 28 July 2021).

10. Karczewski, K.J.; Francioli, L.C.; Tiao, G.; Cummings, B.B.; Alföldi, J.; Wang, Q.; Collins, R.L.; Laricchia, K.M.; Ganna, A.; Genome Aggregation Database Consortium; et al. The Mutational Constraint Spectrum Quantified from Variation in 141,456 Humans. Nature 2020, 581, 434-443. [CrossRef] [PubMed]

11. Peña-Chilet, M.; Roldán, G.; Perez-Florido, J.; Ortuño, F.M.; Carmona, R.; Aquino, V.; Lopez-Lopez, D.; Loucera, C.; FernandezRueda, J.L.; Gallego, A.; et al. CSVS, a Crowdsourcing Database of the Spanish Population Genetic Variability. Nucleic Acids Res. 2021, 49, D1130-D1137. [CrossRef]

12. Landrum, M.J.; Lee, J.M.; Benson, M.; Brown, G.R.; Chao, C.; Chitipiralla, S.; Gu, B.; Hart, J.; Hoffman, D.; Jang, W.; et al. ClinVar: Improving Access to Variant Interpretations and Supporting Evidence. Nucleic Acids Res. 2018, 46, D1062-D1067. [CrossRef] [PubMed]

13. Sim, N.-L.; Kumar, P.; Hu, J.; Henikoff, S.; Schneider, G.; Ng, P.C. SIFT Web Server: Predicting Effects of Amino Acid Substitutions on Proteins. Nucleic Acids Res. 2012, 40, W452-W457. [CrossRef] [PubMed]

14. Adzhubei, I.A.; Schmidt, S.; Peshkin, L.; Ramensky, V.E.; Gerasimova, A.; Bork, P.; Kondrashov, A.S.; Sunyaev, S.R. A Method and Server for Predicting Damaging Missense Mutations. Nat. Methods 2010, 7, 248-249. [CrossRef] [PubMed]

15. Schwarz, J.M.; Cooper, D.N.; Schuelke, M.; Seelow, D. MutationTaster2: Mutation Prediction for the Deep-Sequencing Age. Nat. Methods 2014, 11, 361-362. [CrossRef]

16. Jagadeesh, K.A.; Wenger, A.M.; Berger, M.J.; Guturu, H.; Stenson, P.D.; Cooper, D.N.; Bernstein, J.A.; Bejerano, G. M-CAP Eliminates a Majority of Variants of Uncertain Significance in Clinical Exomes at High Sensitivity. Nat. Genet. 2016, 48, 1581-1586. [CrossRef]

17. Choi, Y.; Chan, A.P. PROVEAN Web Server: A Tool to Predict the Functional Effect of Amino Acid Substitutions and Indels. Bioinformatics 2015, 31, 2745-2747. [CrossRef]

18. Kircher, M.; Witten, D.M.; Jain, P.; O’Roak, B.J.; Cooper, G.M.; Shendure, J. A General Framework for Estimating the Relative Pathogenicity of Human Genetic Variants. Nat. Genet. 2014, 46, 310-315. [CrossRef] [PubMed]

19. Cooper, G.M.; Stone, E.A.; Asimenos, G.; NISC Comparative Sequencing Program; Green, E.D.; Batzoglou, S.; Sidow, A. Distribution and Intensity of Constraint in Mammalian Genomic Sequence. Genome Res. 2005, 15, 901-913. [CrossRef] 
20. Hubisz, M.J.; Pollard, K.S.; Siepel, A. PHAST and RPHAST: Phylogenetic Analysis with Space/Time Models. Brief. Bioinform. 2011, 12, 41-51. [CrossRef]

21. Richards, S.; Aziz, N.; Bale, S.; Bick, D.; Das, S.; Gastier-Foster, J.; Grody, W.W.; Hegde, M.; Lyon, E.; ACMG Laboratory Quality Assurance Committee; et al. Standards and Guidelines for the Interpretation of Sequence Variants: A Joint Consensus Recommendation of the American College of Medical Genetics and Genomics and the Association for Molecular Pathology. Genet. Med. 2015, 17, 405-423. [CrossRef]

22. McClelland, C.; Manousakis, G.; Lee, M.S. Progressive External Ophthalmoplegia. Curr. Neurol. Neurosci. Rep. 2016, 16, 53. [CrossRef] [PubMed]

23. Orsucci, D.; Angelini, C.; Bertini, E.; Carelli, V.; Comi, G.P.; Federico, A.; Minetti, C.; Moggio, M.; Mongini, T.; Santorelli, F.M.; et al. Revisiting Mitochondrial Ocular Myopathies: A Study from the Italian Network. J. Neurol. 2017, 264, 1777-1784. [CrossRef] [PubMed]

24. Virgilio, R.; Ronchi, D.; Hadjigeorgiou, G.M.; Bordoni, A.; Saladino, F.; Moggio, M.; Adobbati, L.; Kafetsouli, D.; Tsironi, E.; Previtali, S.; et al. Novel Twinkle (PEO1) Gene Mutations in Mendelian Progressive External Ophthalmoplegia. J. Neurol. 2008, 255, 1384-1391. [CrossRef] [PubMed]

25. Garone, C.; Taylor, R.W.; Nascimento, A.; Poulton, J.; Fratter, C.; Domínguez-González, C.; Evans, J.C.; Loos, M.; Isohanni, P.; Suomalainen, A.; et al. Retrospective Natural History of Thymidine Kinase 2 Deficiency. J. Med. Genet. 2018, 55, 515-521. [CrossRef]

26. Cohen, B.H. Mitochondrial and Metabolic Myopathies. Contin. Lifelong Learn. Neurol. 2019, 25, 1732-1766. [CrossRef]

27. Domínguez-González, C.; Hernández-Laín, A.; Rivas, E.; Hernández-Voth, A.; Sayas Catalán, J.; Fernández-Torrón, R.; FuizaLuces, C.; García García, J.; Morís, G.; Olivé, M.; et al. Late-Onset Thymidine Kinase 2 Deficiency: A Review of 18 Cases. Orphanet J. Rare Dis. 2019, 14, 100. [CrossRef]

28. Davis, R.L.; Liang, C.; Sue, C.M. A Comparison of Current Serum Biomarkers as Diagnostic Indicators of Mitochondrial Diseases. Neurology 2016, 86, 2010-2015. [CrossRef]

29. Poulsen, N.S.; Madsen, K.L.; Hornsyld, T.M.; Eisum, A.-S.V.; Fornander, F.; Buch, A.E.; Stemmerik, M.G.; Ruiz-Ruiz, C.; Krag, T.O.; Vissing, J. Growth and Differentiation Factor 15 as a Biomarker for Mitochondrial Myopathy. Mitochondrion 2020, 50, 35-41. [CrossRef]

30. Peñas, A.; Fernández-De la Torre, M.; Laine-Menéndez, S.; Lora, D.; Illescas, M.; García-Bartolomé, A.; Morales-Conejo, M.; Arenas, J.; Martín, M.A.; Morán, M.; et al. Plasma Gelsolin Reinforces the Diagnostic Value of FGF-21 and GDF-15 for Mitochondrial Disorders. Int. J. Mol. Sci. 2021, 22, 6396. [CrossRef]

31. Braz, L.P.; Ng, Y.S.; Gorman, G.S.; Schaefer, A.M.; McFarland, R.; Taylor, R.W.; Turnbull, D.M.; Whittaker, R.G. Neuromuscular Junction Abnormalities in Mitochondrial Disease: An Observational Cohort Study. Neurol. Clin. Pract. 2021, 11, 97-104. [CrossRef]

32. Engel, A.G.; Shen, X.-M.; Selcen, D.; Sine, S.M. Congenital Myasthenic Syndromes: Pathogenesis, Diagnosis, and Treatment. Lancet Neurol. 2015, 14, 420-434. [CrossRef]

33. Ciafaloni, E. Myasthenia Gravis and Congenital Myasthenic Syndromes. Contin. Lifelong Learn. Neurol. 2019, 25, 1767-1784. [CrossRef] [PubMed]

34. Ostos, F.; Alcantara Miranda, P.; Hernández-Laín, A.; Domínguez-González, C. Congenital Ophthalmoplegia and Late-Onset Limb Weakness Caused by MUSK Mutations. J. Clin. Neuromuscul. Dis. 2020, 21, 222-224. [CrossRef]

35. Brais, B. Oculopharyngeal Muscular Dystrophy. In Handbook of Clinical Neurology; Elsevier: Amsterdam, The Netherlands, 2011; Volume 101, pp. 181-192. ISBN 978-0-08-045031-5.

36. Wong, K.T.; Dick, D.; Anderson, J.R. Mitochondrial Abnormalities in Oculopharyngeal Muscular Dystrophy. Neuromuscul. Disord. 1996, 6, 163-166. [CrossRef]

37. Alonso-Jimenez, A.; Kroon, R.H.M.J.M.; Alejaldre-Monforte, A.; Nuñez-Peralta, C.; Horlings, C.G.C.; van Engelen, B.G.M.; Olivé, M.; González, L.; Verges-Gil, E.; Paradas, C.; et al. Muscle MRI in a Large Cohort of Patients with Oculopharyngeal Muscular Dystrophy. J. Neurol. Neurosurg. Psychiatry 2019, 90, 576-585. [CrossRef] [PubMed]

38. Pasnoor, M.; Dimachkie, M.M.; Farmakidis, C.; Barohn, R.J. Diagnosis of Myasthenia Gravis. Neurol. Clin. 2018, 36, 261-274. [CrossRef] [PubMed] 